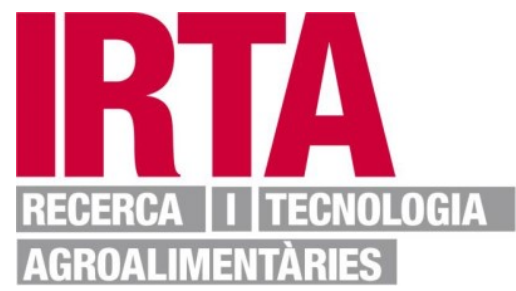

This is a post-peer-review, pre-copyedit version of an article published in European Food Research and Technology. The final authenticated version is available online at: https://doi.org/10.1007/s00217-020-03630-9

Document downloaded from:

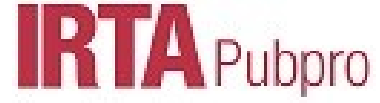

Open digital archive 


\section{Plant-based meat analogues: From niche to mainstream}

\section{Fatma Boukid*}

3 Institute of Agriculture and Food Research and Technology (IRTA), Food Safety Programme, Food

4 Industry Area, Finca Camps i Armet s/n, 17121 Monells, Catalonia, Spain;

$5 \quad *$ Corresponding author: fatma.boukid@irta.cat

\section{Abstract:}

9 Meat analogues are gradually moving from niche to mainstream products. These products are gaining 10 popularity due to surging consumer demand for plant-based products as "better for you" and "better for the

11 planet" alternatives. In this frame, this review aimed to provide the current and forthcoming challenges for 12 meat analogues industry by addressing their market growth drivers, formulation, the pros and cons of 13 conventional and innovative processing, safety and healthiness as well as consumers perception and 14 acceptance. Despite the significant improvements made in the flavor and texture of plant-based meat 15 analogues, food industries still have difficulties in delivering the right sensory experience and there is 16 increased request for sustainable, nutritious and clean label ingredients. For shaping the future of plant17 based meat analogues, the main driver is sustainable nutrition through prompting further improvements in 18 formulation [by enhancing proteins functionally (pre/post-processing) and healthiness (blending plant 19 proteins with tailored nutritional makeup and reducing salt contents)] and processing [by finding solutions 20 to their "processed" and "ultra-processed" nature]. In the future, meat analogue companies will keep 21 pushing the boundaries to mimic meat experience (by improving taste and healthiness) as well as reduce 22 product price and increase product convenience.

24 Keywords: plant proteins, health, nutrition, sustainability, consumer acceptance 


\section{Introduction}

Meat is an important component of the daily diet providing essential elements for human body including protein, fats, vitamins, and minerals [1]. The global meat market is estimated to grow at a compound annual growth rate of $7.35 \%$ during the forecast period 2020-2025 (Research and Markets, 2020). Nevertheless, meat consumption patterns are unpredictable due to constant changes in consumer behavior towards meat [3-5]. Several factors can influence consumer decision including price, appearance, convenience, quality, safety, social, individual, economic, and cultural aspects [3-6]. In the recent years, shift in preferences towards the consumption of plant-based products has been evident since health conscious consumers are seeking safe and healthy products [5]. Despite the health benefits of meat consumption, a diet rich in meat can be related to human issues due to the high content of cholesterol and saturated fatty acids [7, 8]. However, plant-based diets were reported to be cost-effective and with reduced risk towards cardiovascular disease, blood pressure, diabetes, and mortality [9-11]. Media also contributed in changing the dietary habits through promoting the healthiness and sustainability of plant-based products over those animal-based [6]. Population growth (expected to reach 9 billion by 2050) can be a factor pushing the rising interest in plant-based meat to respond to the increasing demand to proteins and to limit the sustainability issues associating animal proteins to increasing feed supplies and higher levels of greenhouse gases production [12]. Furthermore, ethical and religious issues are prevailing concerns surrounding animal-based proteins [13]. As an effective alternative, the development of plant-based meat analogues to replace animal products has created significant breaks for food industries against the above mentioned health, environmental and ethical concerns $[12,14,15]$. Recent studies of life cycle assessment indicated that plant-based meat analogues had a lower environmental impact than meat [16, 17]. These alternative products have a large potential for reducing greenhouse gas emissions (up to $583 \mathrm{MtCO} 2 \mathrm{e}$ per year) and improving nutritional outcomes (up to 52,700 premature deaths avoided per year), but the expected sustainability gains from meat alternatives differ widely based on the ingredients and the process $[18,19]$. The potential of meat analogues for climate change mitigation is strongly dependent on price reductions and consumers acceptability of the different type of meat analogues including cultured meat, mycoprotein and plant-based meat [20-22].

Plant-based meat analogues are particularly booming in the market, going from niche to more mainstream, with more than 6485 launches of new products worldwide since 2015 [23]. By definition, plant-based meat analogues (also called meat substitutes, mock meat, or faux meat) are plant-based products that mimic the appearance, flavor and the fibrous texture of animal meat [20,21]. Various plant protein sources (e.g. cereals, vegetables, legumes, microalgae and fungi) are used to substitute animal proteins for the production of a wide spectrum of meat-free products such as burger patties, sausages, and nuggets [24-27]. In this frame, this article is focused on the main aspects of plant-based meat analogue industry based on critical 
compilation of scientific studies to: i) address their market position and the drivers of their growth compared to other meat analogues types, ii) elucidate their formulation with emphasis on the growing range of ingredients, ii) discuss innovative and conventional processing used of meat analogues texturization, iii) discuss the healthiness of the safety of the ingredients used and finally iv) underline the drivers and the obstacles toward consumer acceptance of these products.

\section{Market landscape: growth, segmentation and drivers}

Meat analogue products are witnessing a great expansion, where the global market is estimated to account for USD 1.6 billion in 2019 and is projected to reach USD 3.5 billion by 2026, recording a compound annual growth rate of $12.0 \%$ during the forecast period (Markets and Markets, 2020). Europe (51.5\%) holds the largest share of the global market followed by North America (26.8\%), Asia Pacific (11.8\%), Latin America (6.3\%) and Middle East \& Africa (3.6\%). The top 10 players are Beyond Meat followed by Boulder Brands, Hain Celestia, Nestlé, Garden Protein International, Vivera, Lightlife Foods, Woolworths, Naturli' Foods and Sainsbury's [23]. The main plant-based proteins used in meat analogues formulations are soy proteins $(63.3 \%$ of total products; isolates $20.3 \%$, concentrates $33.4 \%$ and textured $9.6 \%$ ) followed by wheat (46.8\% of total products; 'wheat protein $14.7 \%$ and gluten $32.1 \%$ ), pea ( $40.2 \%$ of total products; isolates $12.2 \%$ and concentrates $28.4 \%$ ), rice protein (7.2\%) and vegetable proteins (4.7\%) [23].

The main drivers of market growth are attributed to plant meat substitutes association with "better for you" and "better for the planet" tends. Plant-based meat substitutes have been promoted as healthier sources of proteins compared to meat offering health benefits that may play a role in reducing meat consumption [6, 24]. Meat analogs are plant-based protein products that contain highly beneficial essential amino acids, low saturated fat, and are cholesterol-free [29], whereas numerous studies reported the potential links between high consumption of meat products and health issues [30]. The ethical-conscious consumer switched towards plant-based products due to the environmental burden of animal protein production on global warming and resource consumption [14, 31]. Environmental research and life cycle assessments underlined the positive impact of plants (e.g. legumes) on preserving soil fertility, conservation agriculture and biodiversity [32-34]. Ethically, animal welfare rights have also contributed in switching consumer preferences [35-37]. Thus, rising niches of ethical and health-conscious consumers mainly vegans, vegetarian and flexitarians greatly contributed in shaping the market of meat analogue, where most of marketed meat analogues have health and nutrition claims mainly vegan (78.1\%), vegetarian (32\%), high/added protein (37.1\%) and gluten-free (31.3\%) [23]. Flexitarians following semi-vegetarian diet are a 
key segment driving the plant-based meat analogue boom as their gateway for a more sustainable and healthier meat substitute [38].

91 In the future, plant-based meat might have to compete with cultured meat, which is not currently 92 commercialized since it has to fulfill food safety standards [39]. Considering the scenario that cultured meat 93 is proven safe, consumer acceptance toward plant-based meat will be strongly endorsed by: i) familiarity 94 since plant based meat are described "familiar" contrary to cultured meat described as an "unfamiliar" food; 95 ii) ethical concerns over the use of animal cells isolated from slaughtered animals and the use serum bovin foetal as the cells growth media; iii) high level of cell multiplication that might induce some dysregulation similarly to cancer cells; and iv) relatively high production costs and controversial foot printings impact of cultured meat [39-42]. Likewise, ethical cultured meat is still a challenge, where animals' cells are isolated from egg to resolve the ethical issue [43]. Therefore, plant-based meat analogues present numerous advantages compared to conventional meat and cultured meat thereby contributing in reinforcing their position in the market.

\section{Formulation}

The major components of fibrous meat analogues are plant proteins (20-50\%), vegetal lipids (0-5\%), polysaccharides (2-30\%) and other ingredients to enable a meat-like experience as summarized in Table 1 [44].

Plant proteins play several roles in structure, color, texture and flavor of meat analogues owing to their tech-functional properties (solubility, emulsification, foaming, viscosity, gelling, flavor binding and film formation) [45-47]. Plant proteins differ in functionality, compositional and nutritional features depending on source, variety, pre-processing, and purity [48]. Plant proteins can be deriving from one source or a

112 blend of sources to achieve a better functionality and nutritional value. Up until now, soy protein is the 113 most used protein used in meat analogue products due to its high functional properties and balanced amino 114 acid composition (protein digestibility-corrected amino acid scores (PDCAAS) of 1.00 comparable to meat) $115[21,49]$. Soy proteins ensure a double role as extenders and binders at low price. However, manufacturers 116 are gradually moving toward 'clean label' and non-genetically modified protein ingredients [50]. Due to its 117 rheological and viscoelastic properties, wheat protein has a long history of use in meat analogues enabling 118 the formation of fibrous-like texture of the final meat products $[46,51]$. Gluten particularly can play the 
role of binder and extender thereby reducing cooking losses during processing. It holds the fiber together in the matrix for meat analogues to stick the product together and remain stable thanks to its functional properties due to its functional properties such as solubility, viscosity, swelling, and water holding capacity [46]. Pea protein is a rising alternative to soy protein owing to its high adaptability, hypo-allergenicity and good functionality, and mostly used in combination with other sources (e.g. gluten) to improve the nutritional and textural attributes of meat analogues [47]. Other proteins from rice and potato are gaining traction specially for formulating gluten-free meat alternatives $[52,53]$. Protein ingredients innovations keep moving towards more diverse portfolios through the use of fava bean protein and mung bean protein as well as novel proteins such as microalgae, seaweed and fungi [12, 26, 54] and sweet lupin (due to the absence of alkaloids) [55]. Insects and single cell proteins are gaining interest as alternative protein sources such as owing to their high nutritional value, high content in proteins, sustainability and affordability [56$58]$.

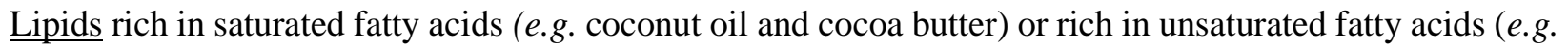
sunflower oil, canola oil, sesame oil and avocado oil) are used to intensify the flavor as well as to improve texture and mouthfeel [59-62]. The source and composition of fatty acids is extremely important to mimic meat flavor related to lipid oxidation and volatiles generated by Maillard reaction during thermal processing [63]. From a nutritional perspective, vegetable oils are cholesterol-free, and thereby considered healthier than animal fats; but more attention must be paid to the composition in unsaturated and saturated fatty acids to create meat-like sensory attributes [64]. Oleogels might be an interesting strategy to substitute saturated fats in plant-based meat alternatives [65]. The application of fiber rich ingredients such as oat-hull-based ingredient or oat's soluble fiber ( $\beta$-glucan) as fat-free fat replacers thanks to the water binding ability of $\beta$ glucan improving the structural characteristics of reduced-fat products $[66,67]$.

Polysaccharides play important functional and structural roles in shaping meat analogues owing to their thickening/emulsifying properties generally required to improve the consistency and water binding [61, 68 , 69]. Native starches and flours (e.g. potato, corn, wheat, cassava, pea and rice) are used mainly as fillers ingredients to improve the texture and consistency $[49,70]$. Fibers from different sources (e.g. pea, potato, oat, soybean, Bamboo, citrus and apple) and polysaccharide gums (e.g. xanthan gum, gum Arabic, carrageenan and alginate) enable thickening and reducing cooking loss of the product due to their high water holding capacity through creating stable oil/water emulsions [71].

Flavoring ingredients such as savory yeast extract, paprika, sugar, spices and herbs, are added to mimic/compensate the aromatic profile of meat products and to mask off-flavors of legume proteins. 
Coloring agents such as annatto extracts (E 160b), lycopene, beet juice extract or leghemoglobin, are used to mimic meat red color; while titanium dioxide is used to mimic chicken color [47, 53, 72-74]. To ensure heat stability of these pigments, other ingredients are added including ascorbic acid or juices rich in polyphenols and ascorbic acid (e.g. apple extract and citrus fruit extracts) [47, 75]. These juices also play the role of antimicrobial and preservative agents ensuring quality stability and shelf-life extension. More research is required to find "clean label" and heat stable colorants.

Fortification ingredients (minerals, amino acids and vitamins) are included to enhance the nutritional value of meat analogues. Health-beneficial ingredients naturally found in animal products such as tocopherols, zinc gluconate, thiamine hydrochloride, sodium ascorbate, niacin, pyridoxine hydrochloride, riboflavin, and cobalamin are added to replicate the composition of meat and to enable to meet the recommended daily allowance [76]. Vitamin B12 is one of the main supplement required by vegans to reach the recommended daily intake [77]. Beside their health benefits, these ingredients can play relevant roles in enhancing meat analogue quality, storage and lipid oxidation. Noteworthy, vitamins and minerals can be added as purified ingredients or within matrices such microalgae, mushrooms or pulses flours $[26,78]$.

\section{Texturizing techniques}

The development of the flavor and fibrous structure of meat analogue is strongly related to the ingredients and processing [29]. Beside proteins, non-protein ingredients play an important role in the solidification and the flavoring of meat analogues [12]. Texturizing multiphase blends (e.g. protein and polysaccharides) results in anisotropic material whilst pure proteins result in an isotropic material $[79,80]$. Texturization is a crucial step since consumers expect a product with similar texture, mouth-feeling, taste, and nutritional value to those of meat products [12]. To mimic the fibrousness of meat muscle, plant-based proteins must go through a series of transformations from their native form (globular shape) to obtain textured protein (linear shape) by applying different processing (e.g. extrusion, wet or electro-spinning, high temperature conical simple shearing, freeze structuring, blends proteins- hydrocolloids and 3D printing) (Table 2).

Extrusion is the most traditional patented process for protein texturization and still one of the most used process due to its high productivity, low cost, versatility, and energy efficiency [81, 82]. In addition, extrusion denatures heat-labile anti-nutritional factors (e.g. trypsin inhibitors and hemagglutinins) and inactivate hydrolytic enzymes (e.g. lipoxygenases, peroxidases and lipoxidases) and increase protein digestibility $[83,84]$. Noteworthy mentioning that most of extrusion processes and patents were established 
for soy protein, but recently more studies have been carried out focusing on wider range of plant proteins (e.g. pea, microalgae and Cannabis sativa) [26, 29, 47, 85]. Extrusion enable changes in protein conformation (denaturation, unfolding, crosslinking and alignment) due to shearing, heating, compression and cooling to create a meat-like structure (structured aggregates or fibrils) [86]. At low moisture extrusion technology ( $<35 \%$ moisture), meat analogues result with a sponge-like texture requiring a further hydration to create the meat-like texture [87]. However, high moisture extrusion (40-80\%) imparted a fibrous meatlike structure due to a better control of product expansion thereby facilitate fat emulsification, protein gelation, particle restructuring, and shaping $[60,88]$. The use of high temperatures $\left(140-180{ }^{\circ} \mathrm{C}\right)$ during extrusion ensure protein melting and polymerization but also can lead to changes in color due to Maillard reaction, caramelization, hydrolysis, and degradation of pigments $[29,85]$.

High-temperature induced shearing was proved efficient in plant proteins texturization in a simple, mild, and cost-effective way [89]. Two devises with different geometries, cone-on-cone and cylinder-in-cylinder, are used to ensure shear-induced structuring of proteins $[70,90,91]$. The cone-in-cone device is designed so the product is placed in the cavity between both cones (the bottom cone is rotating while the top cone is stationary) enabling its heating via an oil bath from both sides at high sheer stress and high temperatures $\left(95-140{ }^{\circ} \mathrm{C}\right)[47,91]$. In the cylinder-in-cylinder device, the product is placed between two cylinders (stationary outer cylinder and rotating inner cylinder) creating similar shear flow to that of cone-in-cone device [70,92]. Compared to extrusion, shear induced structuring results in a defined fibrous structures due to the combination of simple shear and heat [92]. The heating temperature is a key parameter, since shearing at high temperature $\left(140^{\circ} \mathrm{C}\right)$ yielded a solid anisotropic food texture contrarily to low temperatures resulting in a layered structure [79].

Wet-spinning has a long history for making fibrous protein products [93-96]. In the wet-spinning process, aged, alkaline protein solution was forced through a spinnerette and then immersed into an acid coagulating bath for precipitation and solidification [94]. The resulting filaments $(\approx 20 \mu \mathrm{m}$ thickness) may be bundled together and stretched to orient the molecular structure of the fibers [93]. This process, however, requires pure proteins, low $\mathrm{pH}$, high salt concentrations and chemical additives [70, 97]. Moreover, this process yields large amounts of wastes (wastewater streams from coagulation and washing steps) [79].

Electrospinning has recently gained interest as a cost-effective and scalable technology for the production of very thin fibrils [98]. During electrospinning, a polymer solution is subjected to a strong electric field through a hollow needle or spinneret. When the electrical forces overcome the surface tension of the solution, the generated electrically charged polymer solution travels toward an electrically grounded collector [99]. On their way, the solvent rapidly evaporate and the jets stretch and bend in ultrathin dry 

fibrils $(\approx 100 \mathrm{~nm})$ [100] [101]. In electrospinning process, the most important parameters are associated with polymer properties (type, molecular weight, structure and concentration), solvent properties (viscosity, surface tension and electrical conductivity) and ambient parameters (temperature and relative humidity) [99]. Polymers need to be highly soluble and at high concentration to ensure enough overlapping between the molecules and thus creating, an entangled network and the solution must have the right conductivity, viscosity and surface tension. Proteins are generally difficult to electrospin, expect few proteins such as zein due to its amphiphilic polymeric nature [45, 102]. Mixing plant proteins (e.g. pea proteins and soy protein) with spinnable polymers (e.g. cellulose and maltodextrin) can be a good strategy to ensure the efficiency of this technique [103].

Freeze structuring can also enable the formation of a fibrous structure but it is strongly related to the plant protein source and properties (water holding capacity, solubility and gelation) and freezing/drying conditions (temperature and duration). During this process, proteins are blended with other components until obtaining a uniform emulsion. The resulting blend was molded, frozen (to form ice crystal layers) and dried (steaming, baking or frying) [49]. Drying at high temperature ensure setting the protein fibrous texture (irreversible substantially insoluble form) without melting the ice crystals [104]. Textural properties of proteins can be tailored by modulating freezing conditions (the rate of freezing, $\mathrm{pH}$, the solids content of the material, surface effects, heat exchange effects, degree of confinement, and pressure effects) [104].

Mixing plant proteins and hydrocolloids is also a patented technique for creating meat-like products [105]. A mixture of water, a vegetable fat or oil with a protein (e.g. lupine protein, pea protein, potato protein or rape protein), hydrocolloid(s) (e.g. sodium alginate and methylcellulose) was sheared to form a stable emulsion and a colloidal solution of divalent metal cations. To initiate fiber formation, casein, with the ability to coagulate with cations, was added to the emulsion cations ensuring the entrapment of the anisotropic structures. The formed fibrous can be modulated through the concentration of the hydrocolloids and the divalent metal cations required for the precipitation and the micellar casein.

Bioprinting (3D printing technology) was recently applied to print meat analogues formulated using plant proteins [106]. The concept of this technique is based on the extrusion of a paste made with plant proteins and other components (e.g. water, fat, polysaccharides) through a fine nozzle to build multilayer blocks [107]. The viscosity of the paste is a critical parameter to obtain the required structure, and usually some rheological modifiers are used to achieve the desired rheological properties. The constructed meat analogue go later through a maturation phase in a bioreactor under specific conditions to ensure the stability of structure $[107,108]$. This technique enable the design of products with texture similar to muscle fibers and 
tailored nutritional content. Nevertheless, its major drawbacks are associated with production cost, the complexity of spatial structure and long maturation process [109].

\section{Healthiness and safety}

Health-conscious consumers pay lot of attention to the nutritional profile of meat analogues, where label readers further focus on the healthiness of the ingredients. In a survey ( $\mathrm{n}=137$ products) conducted in Sydney supermarket, plant-based analogues had lower energy, total and saturated fat, but higher carbohydrate, sugars, salt and dietary fiber compared with meat [24]. In these cases, high amounts of fat, sugar and salt were generally used to mask the vegetal notes related to some source (e.g. legumes) or to enhance the texture of the product [24]. Only $4 \%$ of products were low in sodium $(58-1200 \mathrm{mg} / 100 \mathrm{~g})$ and $24 \%$ of products were fortified with vitamin B12, $20 \%$ with iron, and $18 \%$ with zinc [24].

Formulation is important to improve the nutritional attributes of meat analogues through using natural and clean label ingredients. However, in the pursuit of mimicking meat texture appearance and taste, brands rely on the use of several ingredients, where most of them are heavily processed or/and genetically-modified (GMO)[110]. In recent year, a drastic shift was recorded from GMO to free-GMO, where 39\% of launched products are declared GMO-free [23]. Naturalness of the ingredients is gaining traction as consumers are increasingly associating healthy food to natural, recognizable and chemical-free foods. As such, $62 \%$ of products launched since 2015 are claimed natural [23]. In this frame, applying clean label ingredients will further reinforce the position of meat analogue in the market, not only for vegan and vegetarians, but also for consumers looking for healthier food options. In recent years, several natural ingredients have been used to substitute those artificial including red colorants, where most brands are more focusing on clean-label and natural red pigments [72]. In addition, breeding for protein with better nutrition and functionality can reduce antinutrients and off-flavor and increase functionality thereby reducing the level of processing and the need to masking agents. More research are required to find solutions (ingredients or/ and processing) to obtain a fibrous structure through the use of health-beneficial ingredients. On the other hand, meat analogues are generally classified as ultra-processed products hampering their healthy image [111]. Concerns are being raised over the association between level of processing and the risk towards health issues such as to cancer and obesity $[112,113]$. Meat analogues developers', therefore, need to find solutions enabling the use of clean label ingredients and less processed products to meet consumer expectations [111]. 
Different plant protein sources are used to tailor the nutritional profile of meat analogues. Such a variability

274 can give a wide array of choice to consumers and thereby indirectly resolve the issue of allergenicity 275 associated with some proteins (e.g. soy, gluten, fungi and pulses).Beside macronutrients, edible fungi 276 particularly increase lysine, which is one of the limiting amino acids in cereal-derived proteins [114]. 277 Noteworthy, the safety of edible filamentous fungi species is still a work on progress as it is closely related 278 to authenticity, purity and medium composition [115]. Microalgae also ensured the production of meat 279 analogues with high protein content and balanced amino acid composition [26]. Beyond proteins, the 280 addition of Spirulina increased phenols and flavonoids concentrations as well as antioxidant capacity and 281 vitamins (B and E) [12, 26]. Thus, consumers can select the meat analogue products fitting their needs. 282 From a regulatory point of view, novel proteins deriving from seaweed, algae and some fungi species must go through a regulation procedure to prove their safety for human consumption. Legislation are still unclear and warrant further studies on the regulation aspects [116]. Another issue might be the presence of antinutrients that can be naturally found in legumes. Considering that ingredients go through a series of processing (physical, thermal or/and biological) during meat analogue production, these components (thermolabile or thermostable) can be denatured thereby offering a final product with better nutritional value.

Noteworthy, the absence of regulations defining meat analogues denomination, safety standards and criteria creates an ethical dilemma, where consumers will find difficulties to understand the healthiness or not of these products [24]. This give room to speculation and social media pressure to create a "fake" image of plant-based meat for promotion or defamation.

\section{Consumers acceptance : motivators and demotivators}

294 The future of plant-meat analogues development rely on understanding consumer perception. Identifying 295 consumer's motivators and demotivators are deemed necessary for designing meat analogues of the future 296 (Figure 1).

\subsection{Motivators}

Motivations behind consumer's purchasing/consuming plant based meat analogues can be related to 299 conventional drivers (taste, cost, and convenience) or/and emerging drivers (health and wellness, safety, 300 environment, animal welfare and familiarity) [6, 24, 117-119]. Apostolidis and McLeay (2016) showed 301 that consumers' ( $\mathrm{n}=247$ U.K. participants) motivation toward purchasing conventional meat (e.g., pork, beef) or plant-based meat (e.g., soy protein) depended on several factors (meat type, fat content, 
environmental impact, brand, and price) suggesting the complexity of meat-consumption choices. This confirms that providing additional information about product properties (e.g. product nutritional labelling, brand, foot printing) can influence purchasing decisions $[6,24,120,121]$. The strongest motivator was "price" (45\%) followed by environmental impact (17\%), taste (15\%), health (11\%), organic (10\%), and vegetarian (6\%) [6]. Interest in buying plant-based meat also depended on age, income, gender, education and geography [122]. In term of age, millennials preference toward plant-based meat was driven by convenience and environmental impact, while older generations (45-59) were driven by taste and familiarity $[122,123]$. Meat reduction was mostly common among low-income population, while highincome countries consume meat in high quantities [122]. It was also found that meat reduction is more frequent among women than men [124]. Consistently, environmental-conscious consumers were profiled as young (age 18 and 34) female with high educational levels, while health-conscious consumers were female over 55 [123, 125]. A cross-countries (US, China and India) surveys revealed that the attitudinal predictors of purchasing meat analogue in the US were appeal, excitement, and low disgust; whereas healthiness, appeal, tastiness, and sustainability were the primary predictors in China; and sustainability, excitement, necessity, and goodness were predictors of plant-based meat purchase intent in India [123].

Hence, these quantitative surveys revealed the association between consumer's dietary behavior and their motivation to consume/purchase plant-based meat analogue. In this frame, three main categories were identified: meat eaters (i.e. conventional consumers), meat reducers (i.e. flexitarians), and meat avoiders (i.e. vegans and vegetarians) $[6,126]$. Emotional attachment assessment confirmed this classification, where $49 \%$ of respondents demonstrated a highly emotional "attachment" to meat, while $37 \%$ demonstrated a less emotional "avoidance" of meat and 14\% demonstrated a highly emotional "disgust" [127]. Conventional eaters' attachment to meat is closely related to emotional connection and taste [128], while vegetarians or vegans are mainly motivated to avoid meat for ethical concerns (animal and human welfare). Flexitarians are an intermediary group motivated by health, environmental and ethical concerns resulting in meat consumption reduction $[122,127]$. Beside health and environmental concerns, meat reduction can be reinforced by producing plant-based products similar to meat (aspect and taste) [129, 130].

\subsection{Demotivators}

The debate on meat and health can be also in favor of meat consumption since many consumers consider meat products as a crucial part of their diet [131]. Indeed, a cross-country (Belgium, Denmark, Germany, Greece and Poland) survey showed that all participants considered meat as an important source of protein and iron [131]. From a consumer perspective, healthiness of meat is related to animals feeding and growth, 
meat processing, and formulation (clean label ingredients or additives). In addition, participants were concerned about the amount and frequency of meat that one should eat. Consistently, a survey conducted in Swedish schools (fifty-nine students and five teachers from five different schools) showed that meat was perceived as central to nutritional health [132].

Environmental consciousness of meat is still an understood topic [133]. Indeed, a survey conducted on twelve focus groups revealed that most meat eaters showed lack of awareness of the association between meat consumption and climate change [134]. Therefore, these consumers showed less willingness to change their eating patterns [134]. These results highlighted the importance of actions to rise consumers' understanding of environmental issues related to meat production [133]. For conscious meat-eaters, the consumption of meat rely on rationalization, where they deny that animals suffer during slaughtering and that animals worth moral concern [135-137]. They build their justification through considering meat as a natural, normal, and necessary food [135]. Taste and nutritional quality were the most important motivators for eating meat [121]. Furthermore, they associate eating meat with pleasure and enjoyment [134]. Likewise, several studies underlined a cultural fact associating meat consumption to men over women [138, 139]. Familiarity can be a boosting factor for meat consumption as consumers are more familiar to conventional meat, resulting in a less attraction and acceptance to alternatives meat, considered unfamiliar [140, 141]. In this case, innovative foods are rejected and consumers prefer maintaining their usual dietary habits for emotional attachment or/and food neophobia (fear of eating new/unfamiliar foods) $[135,142]$.

\section{Conclusions and future outlooks}

Plant-based meat analogues are a growing food segment to be more than an alternative for vegetarian and vegan customers mainly due to increasing awareness towards meat consumption drawbacks on health and on the environment. Nevertheless, to keep boosting this market growth, further investigations are required to enhance taste and texture. Developing ingredients delivering desirable meat-like texture and flavor as well as selecting/ optimizing processing might be suitable strategies. Based on consumer's segmentation, food manufactures have a plenty of opportunity to persuade consumers willing to reduce meat consumption. In the last years, established food companies as well as startups are launching new products into the market to meet consumer demand. Future interventions and policies are deemed necessary to clarify the regulatory uncertainties surrounding plant-based analogues. Nutritional labelling, and health and nutrition claims are, indeed, an opportunity for brands to promote their new products through creating a solid ground of trust and transparency with consumers. 


\section{Acknowledgments}

369 This work was supported by CERCA Programme (Generalitat de Catalunya).

\section{References}

372 1. Pereira PM de CC, Vicente AF dos RB (2013) Meat nutritional composition and nutritive role in the human diet. Meat Sci. 93:586-592

374 2. ResearchandMarkets (2020) Processed Poultry \& Meat Market Analysis 2020-2025 - Global Market Forecast to Grow at a CAGR of 7.35\% During 2020 and 2025. https://www.globenewswire.com/newsrelease/2020/06/08/2044720/0/en/Processed-Poultry-Meat-Market-Analysis-2020-2025-Global-MarketForecast-to-Grow-at-a-CAGR-of-7-35-During-2020-and-2025.html. Accessed 20 Jul 2020

3. Säll S, Gren IM (2015) Effects of an environmental tax on meat and dairy consumption in Sweden. Food

4. Röös E, Ekelund L, Tjärnemo H (2014) Communicating the environmental impact of meat production: Challenges in the development of a Swedish meat guide. J Clean Prod 73:154-164. https://doi.org/10.1016/j.jclepro.2013.10.037

5. Xazela N, Hugo A, Marume U, Muchenje V (2017) Perceptions of Rural Consumers on the Aspects of Meat Quality and Health Implications Associated With Meat Consumption. Sustainability 9:830. https://doi.org/10.3390/su9050830

6. Apostolidis C, McLeay F (2016) Should we stop meating like this? Reducing meat consumption through substitution. Food Policy 65:74-89. https://doi.org/10.1016/j.foodpol.2016.11.002

7. Vang A, Singh PN, Lee JW, et al (2008) Meats, processed meats, obesity, weight gain and occurrence of diabetes among adults: Findings from adventist health studies. Ann Nutr Metab 52:96-104.

https://doi.org/10.1159/000121365

391 8. Wang Y, Beydoun MA (2009) Meat consumption is associated with obesity and central obesity among US adults. Int J Obes 33:621-628. https://doi.org/10.1038/ijo.2009.45

9. Farmer B, Larson BT, Fulgoni VL, et al (2011) A Vegetarian Dietary Pattern as a Nutrient-Dense Approach to Weight Management: An Analysis of the National Health and Nutrition Examination Survey 1999-2004. J Am Diet Assoc 111:819-827. https://doi.org/10.1016/j.jada.2011.03.012

396 10. Springmann M, Wiebe K, Mason-D'Croz D, et al (2018) Health and nutritional aspects of sustainable diet 
detail. Lancet Planet Heal 2:e451-e461. https://doi.org/10.1016/S2542-5196(18)30206-7

11. Mohamed Z, Terano R, Yeoh SJ, Iliyasu A (2017) Opinions of Non-Vegetarian Consumers Among the Chinese Community in Malaysia Toward Vegetarian Food and Diets. J Food Prod Mark 23:80-98. https://doi.org/10.1080/10454446.2017.1244795

12. Palanisamy M, Töpfl S, Berger RG, Hertel C (2019) Physico-chemical and nutritional properties of meat analogues based on Spirulina/lupin protein mixtures. Eur Food Res Technol 245:1889-1898. https://doi.org/10.1007/s00217-019-03298-w

13. Dekkers BL, Boom RM, van der Goot AJ (2018) Structuring processes for meat analogues. Trends Food Sci. Technol. 81:25-36

14. Hartmann C, Siegrist M (2017) Consumer perception and behaviour regarding sustainable protein consumption: A systematic review. Trends Food Sci. Technol. 61:11-25

15. Malek L, Umberger WJ, Goddard E (2019) Committed vs. uncommitted meat eaters: Understanding willingness to change protein consumption. Appetite 138:115-126. https://doi.org/10.1016/j.appet.2019.03.024

16. Fresán U, Marrin D, Mejia M, Sabaté J (2019) Water Footprint of Meat Analogs: Selected Indicators According to Life Cycle Assessment. Water 11:728. https://doi.org/10.3390/w11040728

17. Smetana S, Mathys A, Knoch A, Heinz V (2015) Meat alternatives: life cycle assessment of most known meat substitutes. Int J Life Cycle Assess 20:1254-1267. https://doi.org/10.1007/s11367-015-0931-6

18. Ritchie H, Reay DS, Higgins P (2018) Potential of Meat Substitutes for Climate Change Mitigation and Improved Human Health in High-Income Markets. Front Sustain Food Syst 2:16. https://doi.org/10.3389/fsufs.2018.00016

19. van der Weele C, Feindt P, Jan van der Goot A, et al (2019) Meat alternatives: an integrative comparison. Trends Food Sci. Technol. 88:505-512

20. Joshi V, Kumar S (2015) Meat Analogues: Plant based alternatives to meat products- A review. Int J Food Ferment Technol 5:107. https://doi.org/10.5958/2277-9396.2016.00001.5

21. Kumar P, Chatli MK, Mehta N, et al (2017) Meat analogues: Health promising sustainable meat substitutes. Crit Rev Food Sci Nutr 57:923-932. https://doi.org/10.1080/10408398.2014.939739

22. Sha L, Xiong YL (2020) Plant protein-based alternatives of reconstructed meat: Science, technology, and challenges. Trends Food Sci. Technol. 102:51-61

23. Mintel (2020) GNPD - Plant proteins in meat substitutes. https://www.gnpd.com/sinatra/analysis/chart_results/search/FlMf6yv1YN/?analysis_id=cc8808dc-ef154dc6-b442-bb162fc327f5\&current_tab=cc8808dc-ef15-4dc6-b442-bb162fc327f5. Accessed 17 Jul 2020

24. Curtain F, Grafenauer S (2019) Plant-based meat substitutes in the flexitarian age: An audit of products on 
supermarket shelves. Nutrients 11:. https://doi.org/10.3390/nu11112603

432 25. Fresán U, Mejia MA, Craig WJ, et al (2019) Meat analogs from different protein sources: A comparison of

433 their sustainability and nutritional content. Sustain 11:. https://doi.org/10.3390/SU11123231

434 26. Caporgno MP, Böcker L, Müssner C, et al (2020) Extruded meat analogues based on yellow, heterotrophically cultivated Auxenochlorella protothecoides microalgae. Innov Food Sci Emerg Technol 59:102275. https://doi.org/10.1016/j.ifset.2019.102275

27. Asgar MA, Fazilah A, Huda N, et al (2010) Nonmeat protein alternatives as meat extenders and meat analogs. Compr Rev Food Sci Food Saf 9:513-529. https://doi.org/10.1111/j.1541-4337.2010.00124.x

28. MarketsandMarkets (2020) Meat Substitutes Market Insights, Share, Analysis And Research Report | COVID-19 impact on Meat Substitutes Market. https://www.marketsandmarkets.com/Market-Reports/meatsubstitutes-market-979.html. Accessed 17 Jul 2020

442 29. Guo Z, Teng F, Huang Z, et al (2020) Effects of material characteristics on the structural characteristics and flavor substances retention of meat analogs. Food Hydrocoll 105: https://doi.org/10.1016/j.foodhyd.2020.105752

30. Bronzato S, Durante A (2017) A contemporary review of the relationship between red meat consumption and cardiovascular risk. Int. J. Prev. Med. 8

31. Siegrist M, Hartmann C (2019) Impact of sustainability perception on consumption of organic meat and

32. Lemken D, Spiller A, Schulze-Ehlers B (2019) More room for legume - Consumer acceptance of meat substitution with classic, processed and meat-resembling legume products. Appetite 143: https://doi.org/10.1016/j.appet.2019.104412

34. Nemecek T, Jungbluth N, i Canals LM, Schenck R (2016) Environmental impacts of food consumption and

35. Hartmann C, Siegrist M (2020) Our daily meat: Justification, moral evaluation and willingness to substitute.

37. Weinrich R (2019) Opportunities for the adoption of health-based sustainable dietary patterns: A review on Food Qual Prefer 80:. https://doi.org/10.1016/j.foodqual.2019.103799 consumer research of meat substitutes. Sustain. 11

38. Dagevos H, Voordouw J (2013) Sustainability and meat consumption: Is reduction realistic? Sustain Sci 
Pract Policy 9:60-69. https://doi.org/10.1080/15487733.2013.11908115

465 39. Stephens N, Di Silvio L, Dunsford I, et al (2018) Bringing cultured meat to market: Technical, socio-

466 political, and regulatory challenges in cellular agriculture. Trends Food Sci. Technol. 78:155-166

467 40. Chriki S, Hocquette JF (2020) The Myth of Cultured Meat: A Review. Front. Nutr. 7:7

468 41. Chauvet DJ (2018) Should cultured meat be refused in the name of animal dignity? Ethical Theory Moral

$469 \quad$ Pract 21:387-411. https://doi.org/10.1007/s10677-018-9888-4

470 42. Gómez-Luciano CA, de Aguiar LK, Vriesekoop F, Urbano B (2019) Consumers' willingness to purchase three alternatives to meat proteins in the United Kingdom, Spain, Brazil and the Dominican Republic. Food Qual Prefer 78:. https://doi.org/10.1016/j.foodqual.2019.103732

473 43. Gourmey (2020) GOURMEY - Ethical foie gras without force-feeding. https://gourmey.com/en/. Accessed $23 \mathrm{Jul} 2020$

44. Fu-Hung Hsieh, Harold E. Huff (2011) US20120093994A1 Meat Analog Compositions and Process

45. Mattice KD, Marangoni AG (2020) Comparing methods to produce fibrous material from zein. Food Res Int 128:. https://doi.org/10.1016/j.foodres.2019.108804

46

Chiang JH, Loveday SM, Hardacre AK, Parker ME (2019) Effects of soy protein to wheat gluten ratio on the physicochemical properties of extruded meat analogues. Food Struct 19:. https://doi.org/10.1016/j.foostr.2018.11.002

47. Schreuders FKG, Dekkers BL, Bodnár I, et al (2019) Comparing structuring potential of pea and soy protein with gluten for meat analogue preparation. J Food Eng 261:32-39. https://doi.org/10.1016/j.jfoodeng.2019.04.022

484 48. Hoehnel A, Axel C, Bez J, et al (2019) Comparative analysis of plant-based high-protein ingredients and their impact on quality of high-protein bread. J Cereal Sci 89:. https://doi.org/10.1016/j.jcs.2019.102816

49. Yuliarti O, Kiat Kovis TJ, Yi NJ (2021) Structuring the meat analogue by using plant-based derived composites. J Food Eng 288:. https://doi.org/10.1016/j.jfoodeng.2020.110138

50. Mintel (2019) The meat substitute ingredients to watch - Mintel. https://clients.mintel.com/insight/the-meatsubstitute-ingredients-to-watch?fromSearch $=\% 3$ Ffreetext\%3DPlant $\% 2520$ meat $\% 2520$ substitutes. Accessed 20 Jul 2020

491

492

52. Avebe (2020) Vegan meat analogues. https://www.avebe.com/vegan-meat-analogues-2/. Accessed $23 \mathrm{Jul}$ 2020

496 53. Beyond Meat (2020) Our Ingredients - Beyond Meat - Go Beyond®. 
https://www.beyondmeat.com/about/our-ingredients/. Accessed 23 Jul 2020

54. Stephan A, Ahlborn J, Zajul M, Zorn H (2018) Edible mushroom mycelia of Pleurotus sapidus as novel protein sources in a vegan boiled sausage analog system: functionality and sensory tests in comparison to commercial proteins and meat sausages. Eur Food Res Technol 244:913-924. https://doi.org/10.1007/s00217-017-3012-1

55. Palanisamy M, Franke K, Berger RG, et al (2019) High moisture extrusion of lupin protein: influence of extrusion parameters on extruder responses and product properties. J Sci Food Agric 99:2175-2185. https://doi.org/10.1002/jsfa.9410

56. Azzollini D, Wibisaphira T, Lakemond CMM, Fogliano V (2019) Toward the design of insect-based meat analogue: The role of calcium and temperature in coagulation behavior of Alphitobius diaperinus proteins. LWT 100:75-82. https://doi.org/10.1016/j.lwt.2018.10.037

57. Smetana S, Pernutz C, Toepfl S, et al (2019) High-moisture extrusion with insect and soy protein concentrates: Cutting properties of meat analogues under insect content and barrel temperature variations. J Insects as Food Feed 5:29-34. https://doi.org/10.3920/JIFF2017.0066

58. Bohrer BM (2019) An investigation of the formulation and nutritional composition of modern meat analogue products. Food Sci. Hum. Wellness 8:320-329

59. Dekkers BL, Emin MA, Boom RM, van der Goot AJ (2018) The phase properties of soy protein and wheat gluten in a blend for fibrous structure formation. Food Hydrocoll 79:273-281.

https://doi.org/10.1016/j.foodhyd.2017.12.033

60. Pietsch VL, Bühler JM, Karbstein HP, Emin MA (2019) High moisture extrusion of soy protein concentrate: Influence of thermomechanical treatment on protein-protein interactions and rheological properties. J Food Eng 251:11-18. https://doi.org/10.1016/j.jfoodeng.2019.01.001

61. Lin S, Huff HE, Hsieh F (2000) Texture and chemical characteristics of soy protein meat analog extruded at high moisture. J Food Sci 65:264-269. https://doi.org/10.1111/j.1365-2621.2000.tb15991.x

62. Emin MA, Quevedo M, Wilhelm M, Karbstein HP (2017) Analysis of the reaction behavior of highly concentrated plant proteins in extrusion-like conditions. Innov Food Sci Emerg Technol 44:15-20. https://doi.org/10.1016/j.ifset.2017.09.013

63. Diez-Simon C, Mumm R, Hall RD (2019) Mass spectrometry-based metabolomics of volatiles as a new tool for understanding aroma and flavour chemistry in processed food products. Metabolomics 15:41

64. Klonoff DC (2007) Replacements for trans fats - Will there be an oil shortage? J Diabetes Sci Technol 1:415-422. https://doi.org/10.1177/193229680700100316

65. Martins AJ, Lorenzo JM, Franco D, et al (2019) Omega-3 and Polyunsaturated Fatty Acids-Enriched Hamburgers Using Sterol-Based Oleogels. Eur J Lipid Sci Technol 121:1900111. https://doi.org/10.1002/ejlt.201900111 
66.

Piñero MP, Parra K, Huerta-Leidenz N, et al (2008) Effect of oat's soluble fibre ( $\beta$-glucan) as a fat replacer on physical, chemical, microbiological and sensory properties of low-fat beef patties. Meat Sci 80:675-680. https://doi.org/10.1016/j.meatsci.2008.03.006

67. Summo C, De Angelis D, Difonzo G, et al (2020) Effectiveness of Oat-Hull-Based Ingredient as Fat Replacer to Produce Low Fat Burger with High Beta-Glucans Content. Foods 9:1057. https://doi.org/10.3390/foods9081057

68. Lin S, Huff HE, Hsieh F (2002) Extrusion process parameters, sensory characteristics, and structural properties of a high moisture soy protein meat analog. J Food Sci 67:1066-1072. https://doi.org/10.1111/j.1365-2621.2002.tb09454.x

69. Yao G, Liu KS, Hsieh F (2006) A New Method for Characterizing Fiber Formation in Meat Analogs during High-moisture Extrusion. J Food Sci 69:303-307. https://doi.org/10.1111/j.1365-2621.2004.tb13634.x

70. Krintiras GA, Göbel J, Van Der Goot AJ, Stefanidis GD (2015) Production of structured soy-based meat analogues using simple shear and heat in a Couette Cell. J Food Eng 160:34-41. https://doi.org/10.1016/j.jfoodeng.2015.02.015

71. Zhang J, Liu L, Jiang Y, et al (2020) High-moisture extrusion of peanut protein-/carrageenan/sodium alginate/wheat starch mixtures: Effect of different exogenous polysaccharides on the process forming a fibrous structure. Food Hydrocoll 99:. https://doi.org/10.1016/j.foodhyd.2019.105311

72. Fraser RZ, Shitut M, Agrawal P, et al (2018) Safety Evaluation of Soy Leghemoglobin Protein Preparation Derived From Pichia pastoris, Intended for Use as a Flavor Catalyst in Plant-Based Meat. Int J Toxicol 37:241-262. https://doi.org/10.1177/1091581818766318

73. Oreopoulou V, Tzia C (2007) Utilization of plant by-products for the recovery of proteins, dietary fibers, antioxidants, and colorants. In: Utilization of By-Products and Treatment of Waste in the Food Industry. Springer US, pp 209-232

74. Michael G. Rayner, Jean Luz Rayner, Rachel Miller (2013) US20180220676A1 - Pseudo-loaf food compositions - Google Patents. https://patents.google.com/patent/US20180220676A1/en. Accessed 23 Jul 2020

75. Gregory Trottet, Sheldon Fernandes, Gregor Grunz, et al (2017) US20180064137A1 - A process for preparing a meat-analogue food product

76. Damayanti D, Jaceldo-Siegl K, Beeson WL, et al (2018) Foods and supplements associated with vitamin B12 biomarkers among vegetarian and non-vegetarian participants of the Adventist Health Study-2 (AHS-2) calibration study. Nutrients 10:. https://doi.org/10.3390/nu10060722

77. Office of Dietary Supplements (ODS) (2020) Vitamin B12 - Health Professional Fact Sheet. https://ods.od.nih.gov/factsheets/VitaminB12-HealthProfessional/. Accessed 28 Sep 2020

78. Wi G, Bae J, Kim H, et al (2020) Evaluation of the Physicochemical and Structural Properties and the 
Sensory Characteristics of Meat Analogues Prepared with Various Non-Animal Based Liquid Additives. Foods 9:461. https://doi.org/10.3390/foods9040461

567

568

569

570

571

572

573

574

575

576

577

578

579

580

581

582

583

584

585

586

587

588

589

590

591

592

593

594

595

596

597

598

79. Grabowska KJ, Tekidou S, Boom RM, van der Goot AJ (2014) Shear structuring as a new method to make anisotropic structures from soy-gluten blends. Food Res Int 64:743-751. https://doi.org/10.1016/j.foodres.2014.08.010

80. Grabowska KJ, Zhu S, Dekkers BL, et al (2016) Shear-induced structuring as a tool to make anisotropic materials using soy protein concentrate. J Food Eng 188:77-86. https://doi.org/10.1016/j.jfoodeng.2016.05.010

81. La Von Gene Wenger, Elmer John Osterhaus (1975) US4099455A - Double-extrusion apparatus for producing dense, uniformly layered vegetable protein meat analogue - Google Patents

82. Gene Wenger V (1976) METHOD OF PREPARING DENSE, UNIFORMLY LAYERED VEGETABLE PROTEIN MEAT ANALOGUE 75 Inventors: La. 11:761

83. Mazaheri Tehrani M, Ehtiati A, Sharifi Azghandi S (2017) Application of genetic algorithm to optimize extrusion condition for soy-based meat analogue texturization. J Food Sci Technol 54:1119-1125. https://doi.org/10.1007/s13197-017-2524-9

84. Kamau EH, Nkhata SG, Ayua EO (2020) Extrusion and nixtamalization conditions influence the magnitude of change in the nutrients and bioactive components of cereals and legumes. Food Sci. Nutr. 8:1753-1765

85. Zahari I, Ferawati F, Helstad A, et al (2020) Development of High-Moisture Meat Analogues with Hemp and Soy Protein Using Extrusion Cooking. Foods 9:772. https://doi.org/10.3390/foods9060772

86. Zhang J, Liu L, Liu H, et al (2019) Changes in conformation and quality of vegetable protein during texturization process by extrusion. Crit. Rev. Food Sci. Nutr. 59:3267-3280

87. Osen R, Toelstede S, Wild F, et al (2014) High moisture extrusion cooking of pea protein isolates: Raw material characteristics, extruder responses, and texture properties. J Food Eng 127:67-74. https://doi.org/10.1016/j.jfoodeng.2013.11.023

88. Alam MS, Kaur J, Khaira H, Gupta K (2016) Extrusion and Extruded Products: Changes in Quality Attributes as Affected by Extrusion Process Parameters: A Review. Crit Rev Food Sci Nutr 56:445-473. https://doi.org/10.1080/10408398.2013.779568

89. Estrada PD, Berton-Carabin CC, Schlangen M, et al (2018) Protein Oxidation in Plant Protein-Based Fibrous Products: Effects of Encapsulated Iron and Process Conditions. J Agric Food Chem 66:1110511112. https://doi.org/10.1021/acs.jafc.8b02844

90. Krintiras GA, Gadea Diaz J, Van Der Goot AJ, et al (2016) On the use of the Couette Cell technology for large scale production of textured soy-based meat replacers. J Food Eng 169:205-213. https://doi.org/10.1016/j.jfoodeng.2015.08.021

91. Dekkers BL, Nikiforidis C V., van der Goot AJ (2016) Shear-induced fibrous structure formation from a 
pectin/SPI blend. Innov Food Sci Emerg Technol 36:193-200. https://doi.org/10.1016/j.ifset.2016.07.003

600

601

602

603

604

605

606

607

608

609

610

611

612

613

614

615

616

617

618

619

620

621

622

623

624

625

626

627

628

629

630

631

92. Krintiras GA, Göbel J, Bouwman WG, et al (2014) On characterization of anisotropic plant protein structures. Food Funct 5:3233-3240. https://doi.org/10.1039/c4fo00537f

93. Hsin Yang J, Olsen RA (1970) Meat analogs having the fiber structure of meat

94. Huang HC, Hammond EG, Reitmeier CA, Myers DJ (1995) Properties of fibers produced from soy protein isolate by extrusion and wet-spinning. J Am Oil Chem Soc 72:1453-1460.

https://doi.org/10.1007/BF02577837

95. Rampon V, Robert P, Nicolas N, Dufour E (1999) Protein structure and network orientation in edible films prepared by spinning process. J Food Sci 64:313-316. https://doi.org/10.1111/j.1365-2621.1999.tb15890.x

96. Tolstoguzov VB (1988) CREATION OF FIBROUS STRUCTURES BY SPINNERETLESS SPINNING. In: Food Structure. Elsevier, pp 181-196

97. Liu P, Xu H, Zhao Y, Yang Y (2017) Rheological properties of soy protein isolate solution for fibers and films. Food Hydrocoll 64:149-156. https://doi.org/10.1016/j.foodhyd.2016.11.001

98. Wongkanya R, Chuysinuan P, Pengsuk C, et al (2017) Electrospinning of alginate/soy protein isolated nanofibers and their release characteristics for biomedical applications. J Sci Adv Mater Devices 2:309-316. https://doi.org/10.1016/j.jsamd.2017.05.010

99. Kutzli I, Beljo D, Gibis M, et al (2020) Effect of Maltodextrin Dextrose Equivalent on Electrospinnability and Glycation Reaction of Blends with Pea Protein Isolate. Food Biophys 15:206-215. https://doi.org/10.1007/s11483-019-09619-6

100. Nieuwland M, Geerdink P, Brier P, et al (2014) Reprint of “food-grade electrospinning of proteins.” Innov Food Sci Emerg Technol 24:138-144. https://doi.org/10.1016/j.ifset.2014.07.006

101. Kutzli I, Gibis M, Baier SK, Weiss J (2019) Electrospinning of whey and soy protein mixed with maltodextrin - Influence of protein type and ratio on the production and morphology of fibers. Food Hydrocoll 93:206-214. https://doi.org/10.1016/j.foodhyd.2019.02.028

102. Vogt L, Liverani L, Roether J, Boccaccini A (2018) Electrospun Zein Fibers Incorporating Poly(glycerol sebacate) for Soft Tissue Engineering. Nanomaterials 8:150. https://doi.org/10.3390/nano8030150

103. Kutzli I, Griener D, Gibis M, et al (2020) Improvement of emulsifying behavior of pea proteins as plantbased emulsifiers: Via Maillard-induced glycation in electrospun pea protein-maltodextrin fibers. Food Funct 11:4049-4056. https://doi.org/10.1039/d0fo00292e

104. Robert A Boyer, John E Middendorf (1971) US3870808A - Method of producing a meat simulating textured food product

105. Mehran R, Andreas G, Wolfgang M (2013) EP2945490B1 - Method for producing meat substitute products . https://patents.google.com/patent/EP2945490B1/en. Accessed 27 Jul 2020 
106. Novameat (2019) Plant-Based Meat | NOVAMEAT | Barcelona. https://www.novameat.com/. Accessed 27 Jul 2020

107. Godoi FC, Prakash S, Bhandari BR (2016) 3d printing technologies applied for food design: Status and prospects. J. Food Eng. 179:44-54

108. Voon SL, An J, Wong G, et al (2019) 3D food printing: a categorised review of inks and their development. Virtual Phys. Prototyp. 14:203-218

109. Lupton D, Turner B (2018) Food of the Future? Consumer Responses to the Idea of 3D-Printed Meat and Insect-Based Foods. Food Foodways 26:269-289. https://doi.org/10.1080/07409710.2018.1531213

110. Chuck C, Fernandes SA, Hyers LL (2016) Awakening to the politics of food: Politicized diet as social identity. Appetite 107:425-436. https://doi.org/10.1016/j.appet.2016.08.106

111. Mintel (2020) The Future of Animal Proteins, Meat Alternatives: 2020 - Mintel. https://clients.mintel.com/report/the-future-of-animal-proteins-meat-alternatives2020?fromSearch=\%3Ffreetext\%3DPlant\%2520meat\%2520substitutes. Accessed 20 Jul 2020

112. Poti JM, Braga B, Qin B (2017) Ultra-processed Food Intake and Obesity: What Really Matters for HealthProcessing or Nutrient Content? Curr. Obes. Rep. 6:420-431

113. Fiolet T, Srour B, Sellem L, et al (2018) Consumption of ultra-processed foods and cancer risk: Results from NutriNet-Santé prospective cohort. BMJ 360:. https://doi.org/10.1136/bmj.k322

114. Kim K, Choi B, Lee I, et al (2011) Bioproduction of mushroom mycelium of Agaricus bisporus by commercial submerged fermentation for the production of meat analogue. J Sci Food Agric 91:1561-1568. https://doi.org/10.1002/jsfa.4348

115. Lu H, Lou H, Hu J, et al (2020) Macrofungi: A review of cultivation strategies, bioactivity, and application of mushrooms. Compr Rev Food Sci Food Saf. https://doi.org/10.1111/1541-4337.12602

116. Noordam MY, van der Fels-Klerx HJ (2013) Safety of Novel Protein Sources (Insects, Microalgae, Seaweed, Duckweed, and Rapeseed) and Legislative Aspects for Their Application in Food and Feed Production: Safety aspects of novel protein sources.... Compr Rev Food Sci Food Saf 12:662-678. https://doi.org/10.1111/crf3.2013.12.issue-6

117. R Weinrich OE (2019) Preference and willingness to pay for meat substitutes based on micro-algae. Appetite 142:104353

118. Aggarwal A, Rehm CD, Monsivais P, Drewnowski A (2016) Importance of taste, nutrition, cost and convenience in relation to diet quality: Evidence of nutrition resilience among US adults using National Health and Nutrition Examination Survey (NHANES) 2007-2010. Prev Med (Baltim) 90:184-192. https://doi.org/10.1016/j.ypmed.2016.06.030

119. Sanchez-Sabate R, Sabaté J (2019) Consumer attitudes towards environmental concerns of meat consumption: A systematic review. Int. J. Environ. Res. Public Health 16 
120. Van Loo EJ, Caputo V, Nayga RM, Verbeke W (2014) Consumers' valuation of sustainability labels on meat. Food Policy 49:137-150. https://doi.org/10.1016/j.foodpol.2014.07.002

121. Stea S, Pickering GJ (2019) Optimizing Messaging to Reduce Red Meat Consumption. Environ Commun 13:633-648. https://doi.org/10.1080/17524032.2017.1412994

122. Neff RA, Edwards D, Palmer A, et al (2018) Reducing meat consumption in the USA: A nationally representative survey of attitudes and behaviours. Public Health Nutr 21:1835-1844. https://doi.org/10.1017/S1368980017004190

123. Bryant C, Szejda K, Parekh N, et al (2019) A Survey of Consumer Perceptions of Plant-Based and Clean Meat in the USA, India, and China. Front Sustain Food Syst 3:11. https://doi.org/10.3389/fsufs.2019.00011

124. Rozin P, Hormes JM, Faith MS, Wansink B (2012) Is Meat Male? A Quantitative Multimethod Framework to Establish Metaphoric Relationships. J Consum Res 39:629-643. https://doi.org/10.1086/664970

125. Hoek AC, Luning PA, Stafleu A, De Graaf C (2004) Food-related lifestyle and health attitudes of Dutch vegetarians, non-vegetarian consumers of meat substitutes, and meat consumers. Appetite 42:265-272. https://doi.org/10.1016/j.appet.2003.12.003

126. Graça J, Calheiros MM, Oliveira A (2015) Attached to meat? (Un)Willingness and intentions to adopt a more plant-based diet. Appetite 95:113-125. https://doi.org/10.1016/j.appet.2015.06.024

127. Graça J, Oliveira A, Calheiros MM (2015) Meat, beyond the plate. Data-driven hypotheses for understanding consumer willingness to adopt a more plant-based diet. Appetite 90:80-90. https://doi.org/10.1016/j.appet.2015.02.037

128. Milford AB, Le Mouël C, Bodirsky BL, Rolinski S (2019) Drivers of meat consumption. Appetite 141:104313. https://doi.org/10.1016/j.appet.2019.06.005

129. Elzerman JE, Hoek AC, van Boekel MAJS, Luning PA (2011) Consumer acceptance and appropriateness of meat substitutes in a meal context. Food Qual Prefer 22:233-240. https://doi.org/10.1016/j.foodqual.2010.10.006

130. Hoek AC, van Boekel MAJS, Voordouw J, Luning PA (2011) Identification of new food alternatives: How do consumers categorize meat and meat substitutes? Food Qual Prefer 22:371-383. https://doi.org/10.1016/j.foodqual.2011.01.008

131. Verbeke W, Pérez-Cueto FJA, Barcellos MD d., et al (2010) European citizen and consumer attitudes and preferences regarding beef and pork. Meat Sci. 84:284-292

132. Bohm I, Lindblom C, Åbacka G, et al (2015) "He just has to like ham" - The centrality of meat in home and consumer studies. Appetite 95:101-112. https://doi.org/10.1016/j.appet.2015.06.015

133. Pohjolainen P, Tapio P, Vinnari M, et al (2016) Consumer consciousness on meat and the environment Exploring differences. Appetite 101:37-45. https://doi.org/10.1016/j.appet.2016.02.012 
134. Macdiarmid JI, Douglas F, Campbell J (2016) Eating like there's no tomorrow: Public awareness of the environmental impact of food and reluctance to eat less meat as part of a sustainable diet. Appetite 96:487493. https://doi.org/10.1016/j.appet.2015.10.011

135. Piazza J, Ruby MB, Loughnan S, et al (2015) Rationalizing meat consumption. The 4Ns. Appetite 91:114128. https://doi.org/10.1016/j.appet.2015.04.011

136. Bastian B, Loughnan S, Haslam N, Radke HRM (2012) Don't mind meat? the denial of mind to animals used for human consumption. Personal Soc Psychol Bull 38:247-256. https://doi.org/10.1177/0146167211424291

137. Bratanova B, Loughnan S, Bastian B (2011) The effect of categorization as food on the perceived moral standing of animals. Appetite 57:193-196. https://doi.org/10.1016/j.appet.2011.04.020

138. Clonan A, Wilson P, Swift JA, et al (2015) Red and processed meat consumption and purchasing behaviours and attitudes: Impacts for human health, animal welfare and environmental sustainability. Public Health Nutr 18:2446-2456. https://doi.org/10.1017/S1368980015000567

139. Rothgerber H (2013) Real men don't eat (vegetable) quiche: Masculinity and the justification of meat consumption. Psychol Men Masculinity 14:363-375. https://doi.org/10.1037/a0030379

140. Pouta E, Heikkilä J, Forsman-Hugg S, et al (2010) Consumer choice of broiler meat: The effects of country of origin and production methods. Food Qual Prefer 21:539-546. https://doi.org/10.1016/j.foodqual.2010.02.004

141. Verbeke W (2015) Profiling consumers who are ready to adopt insects as a meat substitute in a Western society. Food Qual Prefer 39:147-155. https://doi.org/10.1016/j.foodqual.2014.07.008

142. Tuorila H, Hartmann C (2020) Consumer responses to novel and unfamiliar foods. Curr. Opin. Food Sci. $33: 1-8$ 
727 Table 1: Main ingredients of plant-based meat analogues

\begin{tabular}{|c|c|c|c|}
\hline Ingredient & Sources & Main role & References \\
\hline Plant proteins & $\begin{array}{l}\text {-soy, wheat, legumes, pea, lupin, } \\
\text { rice and potato } \\
\text {-microalgae and seaweed }\end{array}$ & $\begin{array}{l}\text { Nutrition, } \\
\text { structure, color, } \\
\text { texture and } \\
\text { flavor tech- } \\
\text { functional } \\
\text { properties }\end{array}$ & {$[56-58]$} \\
\hline Lipids & $\begin{array}{l}\text {-rich in saturated fatty acids (e.g. } \\
\text { coconut oil and cocoa butter) } \\
\text {-rich in unsaturated fatty acids } \\
\text { (e.g. sunflower oil, canola oil, } \\
\text { sesame oil and avocado oil) } \\
\text {-fat replacers: Oleogels and } \\
\text { fibers }\end{array}$ & $\begin{array}{l}\text { Flavor, texture } \\
\text { and mouthfeel }\end{array}$ & [59-62] \\
\hline Polysaccharides & $\begin{array}{l}\text {-native starches } \\
\text {-flours } \\
\text {-fibers }\end{array}$ & $\begin{array}{l}\text { Consistency and } \\
\text { water binding }\end{array}$ & {$[61,68,69]$} \\
\hline Flavoring ingredients & $\begin{array}{l}\text { savory yeast extract, paprika, } \\
\text { sugar, spices and herbs }\end{array}$ & Flavor & {$[78]$} \\
\hline Coloring agents & $\begin{array}{l}\text { lycopene, beet juice extract or } \\
\text { leghemoglobin }\end{array}$ & Meat color & {$[47,53,72-74]$} \\
\hline $\begin{array}{l}\text { Fortification } \\
\text { ingredients }\end{array}$ & $\begin{array}{l}\text { tocopherols, zinc gluconate, } \\
\text { thiamine hydrochloride, sodium } \\
\text { ascorbate, }\end{array}$ & Nutritional value & {$[26,78]$} \\
\hline
\end{tabular}


Table 2: Pros and cons of texturizing technologies of meat analogues

\begin{tabular}{|c|c|c|c|}
\hline Technology & Advantages & Disadvantages & References \\
\hline Extrusion & $\begin{array}{l}\text {-high productivity } \\
\text {-low cost } \\
\text {-versatility } \\
\text {-energy efficiency } \\
\text {-anti-nutritional factors } \\
\text { denaturation } \\
\text {-increase } \\
\text { digestibility }\end{array}$ & $\begin{array}{l}\text { changes in color due to } \\
\text { Maillard reaction, } \\
\text { caramelization, } \\
\text { hydrolysis, and } \\
\begin{array}{l}\text { degradation } \\
\text { pigments }\end{array}\end{array}$ & {$[29,81,82,85]$} \\
\hline $\begin{array}{l}\text { High-temperature } \\
\text { induced shearing }\end{array}$ & $\begin{array}{l}\text {-cost-effective } \\
\text {-produce defined fibrous } \\
\text { structure }\end{array}$ & $\begin{array}{lr}\text {-require } & \text { more } \\
\text { investigations } & \text { for } \\
\text { scaling } & \end{array}$ & {$[47,89,91]$} \\
\hline Wet-spinning & $\begin{array}{l}\text {-produce defined fibrous } \\
\text { protein products }\end{array}$ & $\begin{array}{ll}\text {-requires pure proteins } \\
\text {-low pH } & \\
\text {-high } & \text { salt } \\
\text { concentrations and } \\
\text { chemical additives } & \\
\text {-large amounts of } \\
\text { wastes }\end{array}$ & {$[70,79,97]$} \\
\hline Electrospinning & $\begin{array}{l}\text {-cost-effective } \\
\text {-scalable } \\
\text {-production of very thin } \\
\text { fibrils }\end{array}$ & $\begin{array}{l}\text {-several parameters to } \\
\text { control } \\
\text {-difficulties } \\
\text { electrospin to } \\
\text { proteins }\end{array}$ & {$[45,98,99,102]$} \\
\hline Freeze structuring & $\begin{array}{llr}\text {-modulation of } & \text { textural } \\
\text { properties } & \text { of } & \text { plant } \\
\text { proteins } & & \end{array}$ & $\begin{array}{lr}\text {-several freezing } \\
\text { conditions to optimize } \\
\text { and monitor }\end{array}$ & {$[49,104]$} \\
\hline $\begin{array}{l}\text { Mixing plant proteins } \\
\text { and hydrocolloids }\end{array}$ & $\begin{array}{l}\text {-form fibrous structure } \\
\text { that can modulated }\end{array}$ & $\begin{array}{l}\text {-require hydrocolloids } \\
\text { and the divalent metal } \\
\text { cations for the } \\
\text { precipitation }\end{array}$ & [105] \\
\hline $\begin{array}{l}\text { Bioprinting (3D } \\
\text { printing technology) }\end{array}$ & $\begin{array}{l}\text {-enable the design of } \\
\text { products with texture } \\
\text { similar to muscle fibers } \\
\text {-tailor the nutritional } \\
\text { content of the product }\end{array}$ & $\begin{array}{l}\text {-require maturation } \\
\text { under specific } \\
\text { conditions } \\
\text {-high production cost } \\
\text {-the complexity of } \\
\text { spatial structure }\end{array}$ & [106-108] \\
\hline
\end{tabular}




\section{Consumers acceptance towards plant-based meat analogues}

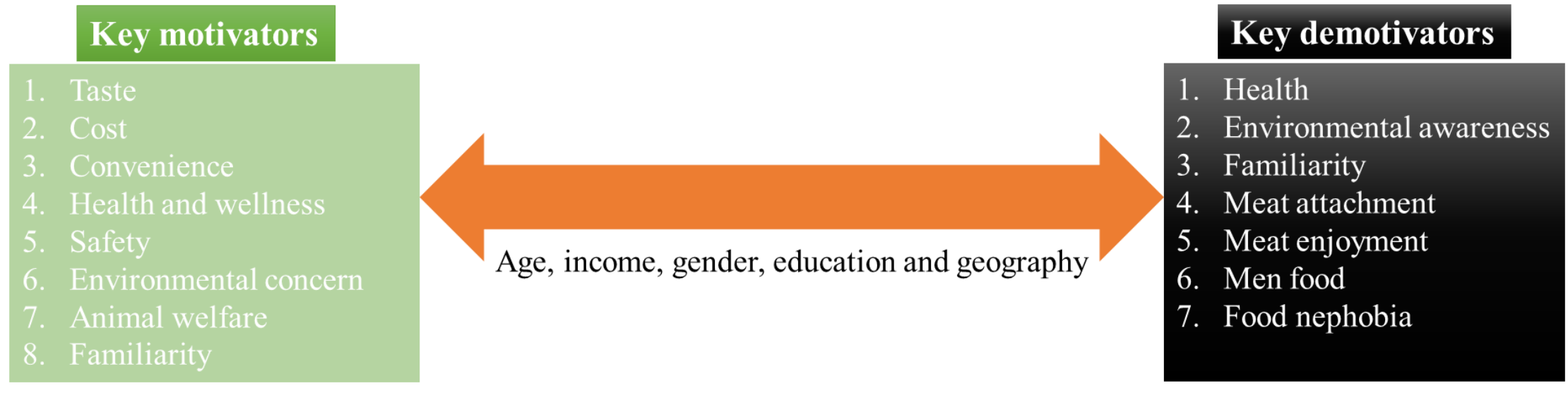

Figure 1: Key factors behind consumers' acceptance to consume/purchase plant-based meat analogues. 
